\title{
PENGEMBANGAN CROSSWORD PUZZLE ACCOUNTING (CPA) BERBASIS ELEKTRONIK SEBAGAI MEDIA PEMBELAJARAN AKUNTANSI
}

\section{DEVELOPING CROSSWORD PUZZLE ACCOUNTING (CPA) ELECTRONIC-BASED AS ACCOUNTANCY LEARNING MEDIA}

\author{
Oleh: \\ Enik Widiastuti \\ Prodi Pendidikan Akuntansi Universitas Negeri Yogyakarta \\ enik.wd26@gmail.com
}

Endra Murti Sagoro

Staf Pengajar Jurusan Pendidikan Akuntansi Universitas Negeri Yogyakarta

\begin{abstract}
Abstrak
Penelitian ini bertujuan untuk: 1) mengembangkan Crossword Puzzle Accounting berbasis elektronik sebagai media pembelajaran Akuntansi. 2) mengetahui kelayakan produk Crossword Puzzle Accounting berbasis elektronik sebagai media pembelajaran Akuntansi berdasarkan validasi ahli materi, ahli media, dan guru akuntansi, 3) mengetahui respon siswa mengenai Crossword Puzzle Accounting berbasis elektronik. Penelitian pengembangan ini mengadaptasi model ADDIE (analysis, design, development, implementation, evaluation) namun dibatasi pada tahap implementasi. Hasil penelitian menunjukkan: 1) Analysis, berdasarkan analisis produk yang sesuai dikembangkan adalah Crossword Puzzle Accounting. 2) Design, pembuatan storyboard; penyusunan materi dan soal; pembuatan background serta penyusunan instrumen penilaian media. 3) Development, pembuatan media, validasi ahli materi dan ahli media, revisi media, dan validasi guru Akuntansi. Tingkat kelayakan media berdasarkan penilaian: (1) ahli materi diperoleh rata-rata 4,36 "Sangat Layak" (2) ahli media 4,26 "Sangat Layak" (3) praktisi pembelajaran Akuntansi 4,38 "Sangat Layak". 4) Implementation, media memperoleh presentase $\geq 65 \%$ yang berarti media mendapat respon positif dari siswa.
\end{abstract}

Kata kunci: Media Pembelajaran, Crossword Puzzle Accounting (CPA), media berbasis elektronik, ADDIE.

\begin{abstract}
This research aimed: 1) develop Crossword Puzzle Accounting (CPA) Electronic-Based for Accountancy Learning Media. 2) Find out the product feasibility of the Crossword Puzzle Accounting (CPA) Electronic-Based Accounting Learning Media based on the validation aspects of materials, media experts, and accountancy teaching practitioners. 3) Find out the students' responses toward the use of electronic-based Crossword Puzzle Accounting (CPA). This research was a development (Research and Development) adapted from ADDIE's development model (analysis, design, development, implementation, and evaluation), yet only carried out up to the implementation phase. The result showed that: 1) Analysis, based on the proper product analysis developed is Crossword Puzzle Accounting. 2) Design, designing a storyboard, arranging the materials and assessmenet, designing th background, and arranging the assesement instrument of the media. 3) Development, designing the media, validation of the media and material experts, revising the media, and validating from the accountancy practitioners/teachers. The feasibility level of the media based on the assessment of the: (1) material expert, obtaining the mean score 4,36 including in the "Very feasible", media expert, obtaining 4,26 as "Very feasible", accountancy practitioners, obtaining 4,38 as "Very feasible". 4) Implementation, the media obtained the percentage $\geq 65 \%$. It meant that the media got a positive response from the students.
\end{abstract}




\section{PENDAHULUAN}

Kualitas sumberdaya manusia merupakan ukuran kemajuan dalam suatu negara. Sumberdaya yang cerdas, kreatif, inovatif, mandiri, dan bertanggung jawab dapat membangun negara yang maju dan mampu bersaing di kancah nasional maupun internasional. Salah satu upaya yang dapat dilakukan untuk meningkatkan kualitas sumberdaya manusia adalah dengan melalui pendidikan.

Pendidikan tidak akan lepas dari proses belajar mengajar. Proses belajar mengajar terjadi karena adanya interaksi antara seseorang dengan lingkungannya. Interaksi yang terjadi selama proses pembelajaran berlangsung akan lebih banyak dipengaruhi oleh pendidik, peserta didik, bahan pelajaran, sumber belajar dan media pembelajaran, sarana dan prasarana, serta pihak manajemen lembaga pendidikan tersebut. Salah satu komponen utama yang bisa mencetak generasi penerus bangsa yang berkualitas adalah seorang pendidik baik di sekolah maupun di lembaga pendidikan nonformal. Pendidik sangat berperan dalam hal ini karena merekalah yang terlibat langsung dalam interaksi yang terjadi dalam proses belajar mengajar. Pendidik menyampaikan pengetahuan, nilai dan norma, serta informasi lainnya kepada peserta didik. Oleh karena itu, pendidik haruslah mengetahui bagaimana cara dan dengan apa menyampaikan informasi agar peserta didik dapat menyerap dan mengamalkan apa yang disampaikannya.

Media pembelajaran merupakan alat bantu guru dalam mengajar serta pembawa pesan dari sumber belajar ke penerima pesan. Artinya sebagai alat bantu, media pembelajaran akan mempermudah guru dalam menyampaikan materi kepada siswa. Media yang biasa digunakan guru dalam proses belajar mengajar adalah dengan menggunakan power point disertai dengan metode ceramah. Namun, beberapa siswa menyatakan bahwa pemakaian media power point disertai dengan metode ceramah terusmenerus sangat membosankan dan kurang menarik. Media pembelajaran harus dikemas sebaik dan semenarik mungkin agar siswa menjadi betah untuk berlama-lama belajar dan mempelajarinya.

Pada masa sekarang ini, ilmu pengetahuan dan teknologi sudah berkembang sangat pesat. Siswa dapat memanfaatkan teknologi untuk belajar dimana saja dan kapan saja serta dengan siapa saja. Namun, pada kenyataannya dari hasil observasi di kelas X AK 2 SMK N 1 Yogyakarta, dalam proses pembelajaran masih sangat bergantung pada guru sebagai sumber belajar atau biasa disebut dengan teacher center. Guru lebih mendominasi proses pembelajaran sehingga siswa menjadi kurang aktif.

Oleh karena itu, dalam kegiatan belajar mengajar media berperan sebagai perantara untuk tersampaikannya informasi materi yang akan diterima oleh siswa. Posisi media ini akan berlaku pada proses pembelajaran di semua cabang ilmu pengetahuan sesuai dengan karakteristik masing-masing ilmu.

Perkembangan ilmu pengetahuan dan teknologi mendorong upaya-upaya pembaharuan dalam pemanfaatan hasil teknologi untuk diterapkan dalam proses belajar. Di samping mampu memanfaatkan sarana dan prasarana yang telah disediakan, pendidik juga diharapkan mampu mengembangkan keterampilan membuat media pembelajaran yang akan digunakannya apabila media tersebut belum tersedia di sekolah. Kenyataannya, pendidik belum maksimal dalam memanfaatkan sarana dan prasarana yang telah disediakan oleh sekolah dan belum dapat mengembangkan media pembelajaran yang inovatif untuk diterapkan dalam proses pembelajaran. "Belajar merupakan proses perubahan tingkah laku melalui pengalaman" 
(Wina Sanjaya, 2012 : 198). Pengalaman tersebut dapat berupa pengalaman langsung maupun pengalaman tidak langsung.

Akuntansi merupakan salah satu cabang ilmu sosial yang cukup unik dibandingkan dengan ilmu sosial yang lain karena di dalamnya dipelajari seni dalam pencatatan keuangan. Mata pelajaran ini sering dianggap sebagai mata pelajaran yang sulit bagi siswa. Hal ini biasa terjadi pada siswa SMK kelas $\mathrm{X}$ yang baru mengenal akuntansi. Anggapan tentang akuntansi berdasarkan hasil interview pada beberapa siswa kelas $X$ AK 2 SMK Negeri 1 Yogyakarta adalah bahwa akuntansi merupakan mata pelajaran yang sulit, rumit, dan membosankan yang salah satunya dipengaruhi oleh penggunaan media yang kurang tepat dalam proses belajar mengajar. Beberapa siswa menyatakan kesulitan pada materi siklus akuntansi perusahaan dagang khususnya mengenai jurnal penyesuaian. Padahal dalam siklus akuntansi perusahaan dagang, jurnal penyesuaian merupakan materi yang penting untuk melanjutkan ke siklus berikutnya. Salah satu upaya yang dapat dilakukan adalah dengan menyediakan media pembelajaran.

Dari hasil observasi di kelas X AK 2 SMK Negeri 1 Yogyakarta, dengan jumlah siswa 32, lebih dari 50\% siswa ramai, berbicara dengan teman sebangku, melamun, bahkan ada beberapa siswa yang mengantuk dalam proses pembelajaran. Selain itu, siswa juga cenderung tidak memperhatikan materi yang disampaikan oleh guru yang salah satunya dikarenakan pembelajaran yang kurang menarik. Berdasarkan interview kepada beberapa siswa di kelas X AK 2 SMK Negeri 1 Yogyakarta, pembelajaran yang kurang menarik salah satunya disebabkan oleh penggunaan media pembelajaran yang kurang bervariasi dan membosankan. Hal tersebut membuat siswa tidak paham terhadap materi yang disampaikan oleh guru dalam proses pembelajaran.

Permasalahan yang paling penting adalah bahwa siswa merasa bosan dan tidak tertarik terhadap pembelajaran yang monoton yaitu dengan metode ceramah dan penggunaan powerpoint. Oleh karena itu siswa membutuhkan inovasi dalam proses pembelajaraannya yaitu berupa media pembelajaran. Media pembelajaran teka-teki silang dirasa cocok untuk menjawab permasalahan di kelas X AK 2 SMK Negeri 1 Yogyakarta karena sesuai dengan apa yang dibutuhkan oleh siswa dalam proses pembelajaran. Teka-teki silang adalah salah satu media yang dapat menarik minat siswa untuk belajar. Hasil penelitian yang sudah dilakukan oleh Tri Yuniyatul Khikmah (2013) yang berjudul Pengembangan Media Pembelajaran CD Interaktif Materi Struktur dan Fungi Sel Dilengkapi Teka-Teki Silang Berbasis Flash menyimpulkan bahwa media pembelajaran yang dilengkapi dengan tekateki silang berbasis flash dapat memotivasi siswa dalam belajar. Terlihat dari hasil tanggapan siswa pada uji coba skala terbatas maupun uji coba skala luas, bahwa sebanyak $100 \%$ siswa menyatakan media pembelajaran menarik motivasi untuk belajar. Hal ini sudah terbukti bahwa media pembelajaran dengan menggunakan teka-teki silang (Crossword Puzzle) dapat menarik siswa dalam belajar, akan tetapi berdasarkan hasil wawancara guru akuntansi di SMK N 1 Yogyakarta, media pembelajaran teka-teki silang (Crossword Puzzle) ini belum banyak digunakan dan dikembangkan sebagai media pembelajaran karena sebagian besar guru akuntansi menggunakan metode ceramah dengan dibantu dengan power point dalam proses pembelajaran.

Crosswords puzzle (teka-teki silang) merupakan sebuah permainan yang cara mainnya yaitu mengisi ruang-ruang kosong yang berbentuk kotak dengan huruf-huruf sehingga membentuk sebuah kata yang sesuai dengan petunjuk. Menurut Hisyam (2002) Crossword Puzzle merupakan salah satu bentuk permainan yang dapat digunakan sebagai strategi pembelajaran yang baik dan menyenangkan tanpa kehilangan esensi belajar yang sedang berlangsung, bahkan dapat melibatkan partisipasi siswa secara aktif sejak awal. Tujuan permainan ini adalah 
untuk menghilangkan atau mengurangi kemonotonan dalam pembelajaran dan menciptakan suasana belajar mengajar yang menyenangkan karena terkesan santai namun tetap fokus pada materi pembelajaran.

Terinspirasi dari Crossword Puzzle yang dimodifikasi menjadi media pembelajaran akuntansi, media ini dinamakan Crossword Puzzle Accounting (CPA). Crossword Puzzle accounting (CPA) merupakan media pembelajaran elektronik yang dibuat dengan mengadaptasi Crossword Puzzlel Teka teki silang. Permainan Crossword Puzzle accounting (CPA) ini hampir sama dengan Crossword Puzzle biasa. Perbedaannya terletak dalam isi dari Crossword Puzzle Accounting (CPA) yaitu fokus pada bahasan materi akuntansi.

Berdasarkan permasalahan yang telah diuraikan di atas, maka peneliti bermaksud melakukan penelitian pengembangan berupa: "Pengembangan Crossword Puzzle Accounting (CPA) Berbasis Elektronik sebagai Media Pembelajaran Akuntansi untuk Siswa Kelas X Akuntansi SMK Negeri 1 Yogyakarta Tahun Ajaran 2015/2016". Tujuan penelitian pengembangan media pembelajaran elektronik Crossword Puzzle Accounting (CPA) untuk mengetahui tingkat kelayakan media pembelajaran tersebut.

Penelitian ini bertujuan untuk 1) mengembangkan Crossword Puzzle Accounting (CPA) Berbasis Elektronik sebagai Media Pembelajaran Akuntansi untuk siswa Kelas X Akuntansi SMK Negeri 1 Yogyakarta Tahun Ajaran 2015/2016. 2) mengetahui kelayakan produk Crossword Puzzle Accounting (CPA) Berbasis Elektronik sebagai Media Pembelajaran Akuntansi untuk siswa Kelas X Akuntansi SMK Negeri 1 Yogyakarta Tahun Ajaran 2015/2016 berdasarkan validasi/penilaian ahli materi, ahli media, dan praktisi pembelajaran akuntansi. 3) mengetahui pendapat/respon siswa mengenai penggunaan Crossword Puzzle Accounting (CPA) Berbasis Elektronik sebagai media pembelajaran Akuntansi.

\section{METODE PENELITIAN \\ Jenis Penelitian}

Penelitian ini menggunakan metode penelitian dan pengembangan (Research and Development).

\section{Waktu dan Tempat Penelitian}

Penelitian ini dilaksanakan di SMK Negeri 1 Yogyakarta yang beralamat di Jalan Kemetiran Kidul No 35 Yogyakarta. Penelitian dilakukan secara bertahap dalam kurun waktu bulan Januari 2016 sampai dengan Juni 2016 yang meliputi tahap perencanaan, penelitian, dan pelaporan.

\section{Target/Subjek Penelitian}

Subjek uji coba yang terlibat adalah dua orang ahli media pembelajaran (dosen jurusan pendidikan Akuntansi UNY), dua orang ahli materi (dosen jurusan pendidikan Akuntansi UNY), praktisi pembelajaran Akuntansi (guru Akuntansi SMK N 1 Yogyakarta), 32 siswa kelas X Akuntansi 2 SMK N 1 Yogyakarta. Objek uji coba yang diteliti adalah kelayakan media pembelajaran yang meliputi aspek relevansi materi, pengorganisasian materi, aspek latihan soal/evaluasi, bahasa, rekayasa perangkat lunak, dan tampilan visual.

\section{Prosedur}

Penelitian ini merupakan penelitian pengembangan (Research and Development) dengan menggunakan model ADDIE oleh Dick and Carry (1996) (dalam Endang Mulyatiningsih 2011: 184). Model pengembangan ADDIE terdiri dari lima tahapan yang meliputi analisis (analysis), desain (design), pengembangan (development), implementasi (implementation), dan evaluasi (evaluation). Namun pada penelitian ini dibatasi hanya sampai tahap implementasi saja karena keterbatasan peneliti.

\section{Data, Instrumen, dan Teknik Pengumpulan Data \\ a. Data}


Data dalam penelitian ini dikumpulkan dengan menggunakan angket. Angket dalam penelitian ini digunakan untuk mengumpulkan data mengenai kelayakan media pembelajaran Crossword Puzzle Accounting (CPA) berbasis elektronik untuk mata pelajaran akuntansi yang diberikan kepada para ahli media, ahli materi, guru akuntansi, dan siswa sebagai subjek uji coba.

Angket digunakan untuk mengukur kelayakan media yang dikembangkan ditinjau dari aspek relevansi materi, pengorganisasian materi, latihan soal/evaluasi, bahasa, rekayasa perangkat lunak, dan tampilan visual. Angket penilaian media untuk ahli materi memiliki 26 indikator, ahli media 15 indikator, guru 26 indikator, serta siswa 6 indikator.

Angket penilaian menggunakan skala likert. Skala likert digunakan untuk mengukur sikap, pendapat, dan persepsi seseorang atau sekelompok orang mengenai suatu fenomena. "Skala likert dalam mengukur penilaian media pembelajaran ini menggunakan lima alternatif jawaban yaitu sangat setuju, setuju, ragu-ragu, tidak setuju, dan sangat tidak setuju" (Sugiyono, 2013: 135). Selanjutnya agar diperoleh data kuantitatif, maka kelima alternatif jawaban diberi nilai yakni sangat setuju = 5 , setuju $=4$, ragu-ragu $=3$, tidak setuju $=2$, dan sangat tidak setuju $=1$.

\section{b. Teknik Analisis Data}

Data yang telah terkumpul akan dianalisis untuk mengetahui penilaian dan pendapat dari media yang dihasilkan.

1) Data proses pengembangan media

Data proses pengembangan media merupakan data deskriptif. Data proses pengembangan media diperoleh alur pembuatan media sampai hasil akhir media.
2) Data penilaian kelayakan media oleh ahli

Data penilaian media diperoleh dari hasil isian angket oleh ahli media, ahli materi, dan guru. Data selanjutnya dianalisis dengan mengikuti langkah-langkah sebagai berikut:

a) Mengubah penilaian kualitatif menjadi kuantitatif dengan ketentuan seperti pada tabel 1 .

Tabel 1. Ketentuan Pemberian Nilai Menurut Sugiyono (2013: 136)

\begin{tabular}{|l|c|}
\hline \multicolumn{1}{|c|}{ Kategori } & Nilai \\
\hline SS (Sangat Setuju) & 5 \\
\hline S (Setuju) & 4 \\
\hline RG (Ragu-ragu) & 3 \\
\hline TS (Tidak Setuju) & 2 \\
\hline STS (Sangat Tidak Setuju) & 1 \\
\hline
\end{tabular}

b) Menghitung nilai rata-rata keseluruhan dan setiap aspek dengan rumus

$$
\begin{array}{ll}
\overline{\mathrm{X}}=\frac{\sum x}{N} & \\
\text { Keterangan: } \\
X \quad=\text { nilai rata-rata, } \\
\sum x \quad=\text { Jumlah nilai, } \\
N \quad=\text { jumlah subjek }
\end{array}
$$

(Sukardjo, 2012: 98)

c) Menginterpretasikan secara kualitatif nilai rata-rata keseluruhan dan tiap aspek dengan menggunakan kriteria sebagai berikut:

Tabel 2. Kriteria Konversi Nilai Menjadi Skala Lima.

\begin{tabular}{|c|l|l|}
\hline No. & Rentang & \multicolumn{1}{c|}{ Kategori } \\
\hline 5 & $4,21-5,00$ & Sangat Layak \\
\hline 4 & $3,41-4,20$ & Layak \\
\hline 3 & $2,61-3,40$ & Cukup Layak \\
\hline 2 & $1,81-2,60$ & Kurang Layak \\
\hline 1 & $0-1,80$ & $\begin{array}{l}\text { Sangat Kurang } \\
\text { Layak }\end{array}$ \\
\hline
\end{tabular}

Keterangan:

Nilai maksimal $\quad=5$ 
Nilai minimal $\quad=1$

(Sukardjo, 2012: 98)

3) Data pendapat siswa

Data berupa pendapat siswa diperoleh dari angket kombinasi tertutup dan terbuka. Alternatif jawaban yang diberikan pada angket tertutup untuk pertanyaan tersebut adalah "Ya" dan "Tidak". Persentase tiap nomor dihitung dengan menggunakan rumus:

\section{Persentase tiap nomor(\%) \\ $=\frac{\text { Jumlah siswa yang menjawab Ya }}{\text { Jumlah seluruh siswa }} \times 100 \%$ \\ (Sunoto, 2007: 37)}

Respon siswa dianggap positif bila mendapat persentase $\geq 65 \%$. Pada bagian angket tertutup, analisis data yang digunakan menggunakan teknik analisis data deskriptif kualitatif (Sunoto, 2007: 38).

\section{HASIL} PENELITIAN

DAN

\section{PEMBAHASAN}

\section{Hasil Penelitian}

a. Tahap Analisis (Analisys)

1) Analisis Kebutuhan Siswa

Berdasarkan observasi di kelas X Ak 2 SMK N 1 Yogyakarta dalam pembelajaran akuntansi, media pembelajaran yang digunakan oleh guru masih terbatas. Guru hanya menggunakan metode ceramah yang dibantu dengan powerpoint Siswa merasa bosan karena media yang digunakan tidak menarik dan kurang bervariasi. Siswa cenderung lebih pasif dalam pembelajaran. Siswa membutuhkan suatu media yang lebih bervariasi yang bisa menarik dalam proses pembelajaran. Berdasarkan observasi tersebut perlu dikembangkan media pembelajaran yang bisa menarik siswa dalam proses pembelajaran yang menyenangkan dan mempunyai suasana baru untuk belajar serta tercapainya tujuan pembelajaran. Media pembelajaran yang dikembangkan yaitu media yang membuat siswa aktif dan tidak merasa bosan dalam proses pembelajaran berlangsung. Media pembelajaran Crossword Puzzle Accounting (CPA) berbasis elektronik ini dikembangkan agar siswa lebih tertarik memperhatikan dan membuat siswa aktif dalam proses belajar mengajar. Selain itu, pemilihan pengembangan media ini untuk memanfaatkan fasilitas sekolah berupa LCD proyektor dan Laboratorium Komputer Akuntansi yang ada maupun laptop yang dimiliki siswa.

2) Analisis Kompetensi dan Instruksional

Analisis kompetensi dan instruksional berkaitan dengan standar kompetensi dan kompetensi dasar yang akan dimuat dalam media. Materi membuat jurnal penyesuaian pada perusahaan dagang sesuai dengan Standar Kompetensi (SK) Menyusun laporan keuangan Akuntansi perusahaan dagang dan Kompetensi Dasar (KD) Membuat jurnal penyesuaian.

Pada tahap analisis instruksional, Kompetensi Dasar tersebut dijabarkan menjadi 6 indikator yaitu:

a) Mendeskripsikan pengertian jurnal penyesuaian

b) Mengidentifikasi akun-akun yang memerlukan jurnal penyesuaian

c) Mengidentifikasi dokumen jurnal penyesuaian

d) Mengidentifikasi akun yang di debet dan di kredit 
e) Mengidentifikasi jumlah rupiah yang di debet dan di kredit

f) Membuat jurnal penyesuaian

b. Tahap Desain (Design)

1) Pembuatan Desain Media (Storyboard)

Storyboard menggambarkan secara keseluruhan hubungan antara bagian dalam media. Storyboard dibuat untuk memudahkan proses pembuatan media selanjutnya dan berfungsi seperti peta pada panduan pembuatan media.

2) Penyusunan materi, soal, dan jawaban

Materi tersebut dipilih bersama guru akutansi kelas X Ak 2 SMK Negeri Yogyakarta. Menurut guru akuntansi kelas X Ak 2, materi akuntansi perusahaan dagang merupakan materi yang sulit terutama pada jurnal penyesuaian dan cakupannyapun banyak. Biasanya pada materi ini siswa kurang bisa memahami apabila dibandingkan dengan materi lain yang lebih mudah. Peneliti mencari buku untuk referensi dalam pembuatan soal-soal yang dimasukkan ke dalam media pembelajaran.

3) Pengumpulan dan pembuatan background, gambar, dan tombol

Gambar yang disajikan dalam media dirancang sendiri oleh peneliti. Sebagian gambar dibuat dengan mengkombinasikan gambar hasil unduhan dari berbagai sumber. Seluruh gambar dibuat dalam format portable network graphics (.png).

4) Perangkat keras (hardware) dan perangkat lunak (software)

Pembuatan media pembelajaran berbasis elektronik khususnya laptop atau komputer memerlukan hardware dan software yang sesuai. Hardware minimal yang dibutuhkan dengan spesifikasi sebagai berikut:

a) Processor Intel Core2Duo (x86 Architecthure)

b) RAM 2 GB

c) Hard Disk 4GB

Syarat minimum yang dibutuhkan untuk menjalankan aplikasi ini pada PC/Laptop yaitu:

a) $2,33 \mathrm{GHz}$ atau lebih cepat $\mathrm{x} 86-$ compatible processor atau intel AtomTM $1,6 \mathrm{GHz}$ atau processor yang lebih cepat untuk perangkat netbook.

b) System type 32-bit operating system atau system type 64-bit yang didukung dengan adanya aplikasi flash player.

c) RAM 512

MB

(direkomendasikan 1GB)

Software yang dibutuhkan adalah sebagai berikut:

a) Macromedia Flash 8 salah satu software plugin untuk mengembangkan desain professional.

b) Notepad ++ , merupakan program aplikasi pengembang yang berguna untuk mengedit teks dan skrip kode pemrogaman.

c) CorelDRAW Graphic Suite X6, merupakan aplikasi desain grafis untuk membuat berbagai desain secara digital.

5) Penyusunan instrumen penilaian kelayakan media

Pada tahap desain juga disusun instrumen penilaian kualitas media berupa angket daftar isian (check list) untuk ahli materi, ahli media, dan praktisi pembelajaran Akuntansi. Sedangkan untuk siswa diberikan angket kombinasi tertutup dan terbuka.

c. Tahap Pengembangan (Development)

1) Pembuatan Media

Pembuatan

media pembelajaran ini menggunakan 
program Macromedia Flash 8 dan hasil akhir media pembelajaran yang dibuat dengan program Macromedia Flash 8 disimpan dalam file ekstensi (.exe) ini bertujuan agar program media pembelajaran dapat dijalanakan dikomputer manapun tanpa menginstall master Macromedia Flash 8.

Adapun tampilan visual dari media pembelajaran menggunakan Program Macromedia Flash 8 yang dikembangkan adalah sebagai berkikut.

a) Tampilan menu utama

Pada tampilan awal terdapat 6 tombol, yaitu tombol home/ beranda/ menu utama, tombol SK/KD, tombol materi, tombol CPA, tombol evaluasi, dan tombol profil.

b) Tampilan menu $S K / K D$

Pilihan tombol menu SK/KD pada halaman menu utama terdapat 3 sub-menu dari SK/KD yaitu submenu Standar Kompetensi (SK), submenu Kompetensi Dasar (KD), dan sub-menu Indikator.

c) Tampilan menu materi

Pilihan tombol menu materi pada beranda/menu utama akan memunculkan tampilan materi yang di dalamnya terdapat tiga pilihan submenu yaitu peta konsep, jurnal penyesuaian, dan contoh jurnal penyesuaian.

d) Tampilan menu CPA

Tampilan menu CPA akan menampilkan tiga tombol yaitu tombol main, bantuan, dan keluar.

e) Tampilan menu evaluasi

Tampilan menu evaluasi berisikan dua pilihan sub-menu yaitu sub-menu evaluasi 1 dan sub-menu evaluasi 2.

f) Tampilan menu profil

Pada tampilan menu profil akan memunculkan biodata pembuat, pengembang, dosen pembimbing, narasumber, ahli media, ahli materi, dan guru akuntansi. g) Tampilan konfirmasi keluar Pengguna tinggal menekan tombol "ya" untuk keluar dari aplikasi.

2) Validasi 1

Pada tahap ini media divalidasi oleh 2 orang ahli materi yaitu Ibu Adeng Pustikaningsih, M.Si. (Dosen Pendidikan Akuntansi FE UNY) sebagai ahli materi 1 dan Ibu Patriani Wahyu Dewanti, M.Acc. (Dosen Pendidikan Akuntansi FE UNY) sebagai ahli materi 2; dan 2 orang ahli media yaitu Ibu Dra. Sumarsih, M.Pd. sebagai ahli media 1 (Dosen Pendidikan Akuntansi FE UNY) dan Bapak Rizqi Ilyasa Aghni, M.Pd. sebagai ahli media 2 (Dosen Pendidikan Akuntansi FE UNY).

a) Validasi ahli materi

Validasi yang dilakukan oleh ahli materi yaitu dengan mengumpulkan saran atau pendapat untuk perbaikan. Penilaian kelayakan media oleh ahli materi 1 memperoleh rata-rata 4,80 dan ahli materi 2 memperoleh rata-rata skor 3,92. Berdasarkan tabel konversi menurut perhitungan Sukardjo (2012: 98) bahwa rata-rata skor 4,80 masuk dalam kategori "sangat layak" sedangkan ratarata skor 3,92 masuk dalam kategori "layak"

Dari kedua hasil penilaian ahli materi memperoleh nilai rata-rata sebesar 4,36 yang masuk dalam kategori "Sangat Layak". Penilaian oleh ahli materi dapat disajikan dalam bentuk diagram batang sebagai berikut: 


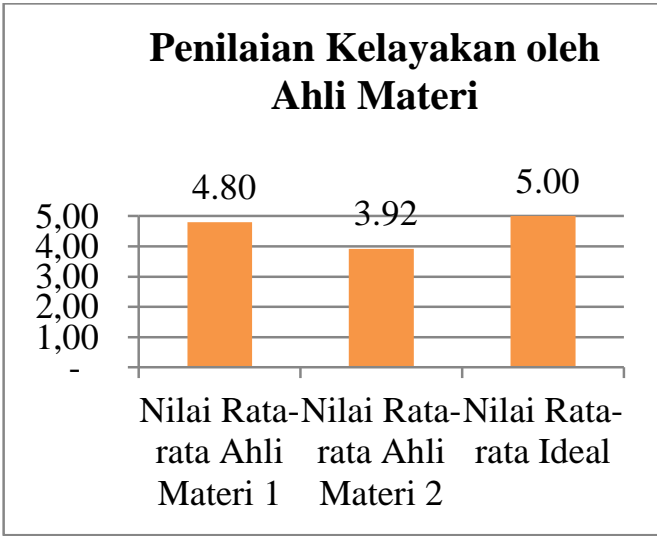

\section{Gambar 1. Diagram Batang Penilaian Kelayakan oleh Ahli Materi Keseluruhan Aspek}

b) Validasi ahli media

Validasi yang dilakukan oleh ahli media yaitu dengan mengumpulkan saran atau pendapat untuk perbaikan. Penilaian kelayakan media oleh ahli media 1 dan 2 memperoleh rata-rata 4,26. Berdasarkan tabel konversi menurut perhitungan Sukardjo (2012: 98) bahwa rata-rata skor 4,26 masuk dalam kategori "sangat layak". Dari kedua hasil penilaian ahli media memperoleh nilai rata-rata sebesar 4,26 yang masuk dalam kategori "Sangat Layak". Penilaian oleh ahli media dapat disajikan dalam bentuk diagram batang sebagai berikut:

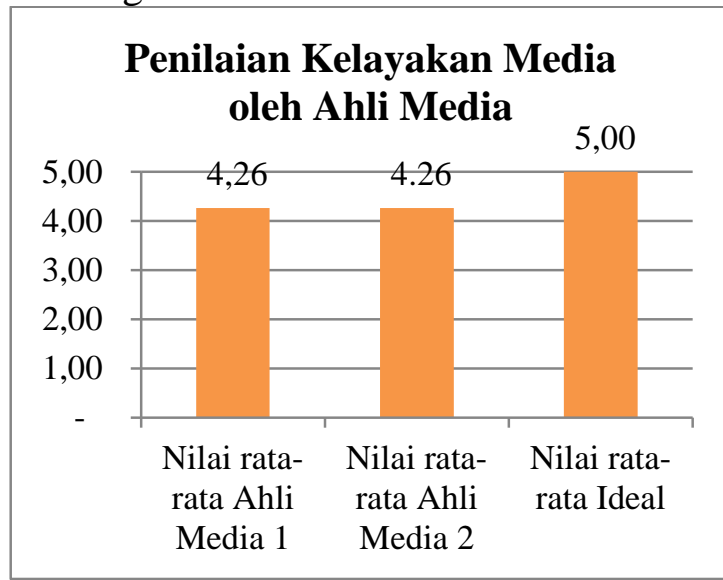

Gambar 2. Diagram Batang Penilaian Kelayakan Ahli Media Keseluruhan Aspek

c) Revisi I

(1) Revisi Ahli Materi 1 (a) Kelengkapan materi dan soal.

(b) Penambahan variasi soal yaitu dengan memasukan nilai pemakaian perlengkapan.

(c) Perlu penambahan variasi soal latihan untuk sub materi persediaan barang dagang menggunakan metode periodik dan perektual.

(2) Revisi Ahli Materi 2

(a) Perbaikan pada kesesuaian indikator dengan materi yang dibahas.

(b) Perbaikan pada peta konsep pengantar materi sebelum masuk pada materi jurnal penyesuaian.

(c) Perbaikan pada penjelasan mengenai akun-akun yang memerlukan penyesuaian dalam perusahaan dagang.

(3) Revisi Ahli Media

(a) Background media sebaiknya disesuaikan dengan jenis/tema media yaitu icon teka-teki silang bukan icon scrabble.

(b) Pemilihan font diganti dengan jenis font yang mudah dan enak dibaca seperti arial, calibri, atau cambria. Selain itu ukuran huruf dibuat 24-26 size.

(c) Tampilan pada sub-materi peta konsep, untuk keterangannya dipindah kesamping kiri atau kanan, jangan menutupi siklus akuntansi lainnya.

(d) Sesuaikan warna background dengan warna tulisan agar mudah di baca khususnya pada bagian materi.

(e) Tampilan soal pada menu CPA dibuat zoom di tengah kotakkotak jawaban dengan diberi keterangan soal nomer.

d) Validasi II

Validasi dilakukan oleh praktisi pembelajaran Akuntansi yang dilakukan oleh Ibu Dra. A. W. Widowati Guru Akuntansi kelas $\mathrm{X}$ AK dan Bapak 
Marsono, S.Pd. Guru Paket Keahlian Akuntansi SMK Negeri 1 Yogyakarta yaitu dengan mengumpulkan saran atau pendapat untuk melakukan revisi.Secara ringkas, rekapitulasi nilai disajikan dalam tabel berikut ini.

Penilaian kelayakan media oleh praktisi pembelajaran Akuntansi 1 memperoleh rata-rata 4,46 dan praktisi pembelajaran Akuntansi 2 memperoleh rata-rata skor 4,43. Berdasarkan tabel konversi menurut perhitungan Sukardjo (2012: 98) bahwa rata-rata skor 4,46 masuk dalam kategori "Sangat Layak" dan rata-rata skor 4,43masuk dalam kategori "Sangat Layak"

Dari kedua hasil penilaian praktisi pembelajaran Akuntansi memperoleh nilai rata-rata sebesar 4,36 yang masuk dalam kategori "Sangat Layak". Penilaian oleh penilaian praktisi pembelajaran Akuntansi dapat disajikan dalam bentuk diagram batang sebagai berikut:

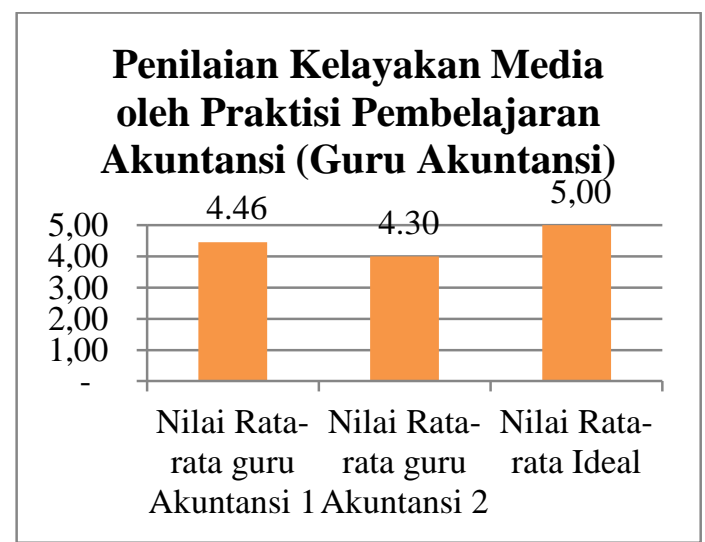

Gambar 3. Diagram Batang Penilaian Kelayakan Praktisi Pembelajaran Akuntansi Keseluruhan Aspek

d. Tahap Implementasi (Implementation) Tahap implementasi dilaksanakan pada 32 siswa tanggal 13 Juni 2016 di kelas X Akuntansi 2 SMK Negeri 1 Yogyakarta yang beralamat di
Jalan Kemetiran Kidul 35, Pringgokusuman, gedongtengen, Yogyakarta. Berikut adalah rekapitulasi jawaban dari 32 siswa kelas $\mathrm{X}$ AK 2 SMK N 1 Yogyakarta.

Dari hasil uji coba diketahui bahwa seluruh pertanyaan mendapatkan "Respon Positif" dengan persentase $\geq$ $65 \%$. Berikut disajikan persentase jawaban siswa setiap pertanyaan dalam bentuk diagram batang.

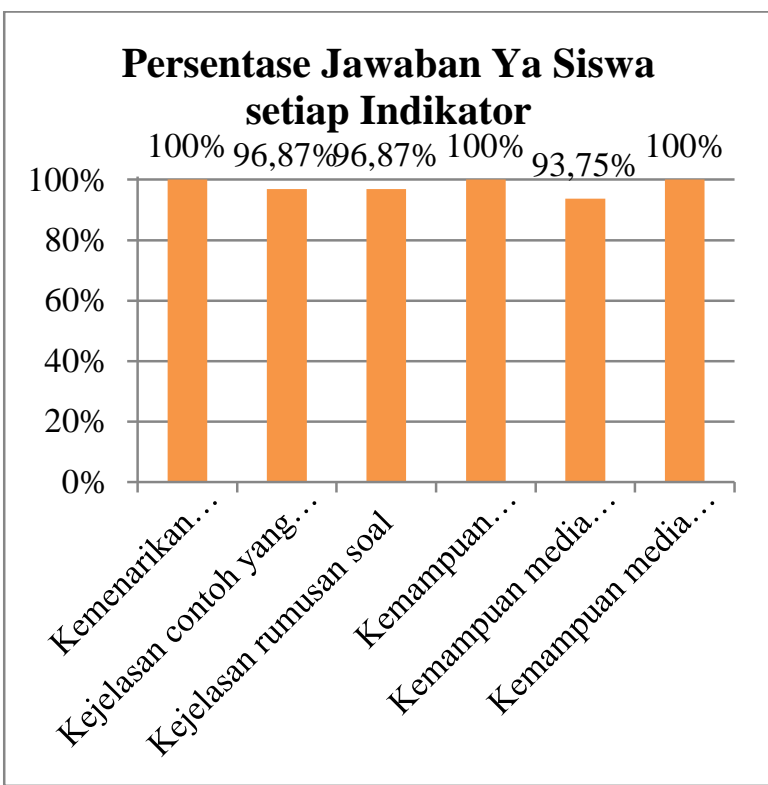

Gambar 4. Diagram Batang Persentase Jawaban Ya Siswa setiap Indikator

Dari diagram batang di atas dapat diketahui bahwa persentase tertinggi pendapat oleh siswa dengan mendapat $100 \%$ yaitu pada indikator kemenarikan penyampaian materi, kemampuan mendorong rasa ingin tahu siswa, dan kemampuan media menambah motivasi siswa dalam belajar. Selanjutnya kejelasan kejelasan contoh yang diberikan dan kejelasan rumusan soal menempati posisi kedua dengan mendapat 96,87\%. Persentase terendah dengan mendapat $93,75 \%$ yaitu pada indikator kemempuan media dalam meningkatkan pemahaman siswa. Hal ini juga didukung oleh beberapa alasan siswa yang menyatakan bahwa media ini menarik 
dan bagus, materi disajikan dengan lengkap, tidak membosankan, media yang lucu, unik dan kreatif, membuat rasa ingin tahu, banyak penjelasannya membuat siswa mempermudah memahami, media yang merupakan hal baru dan belum pernah ada sebelumnya, media menggugah belajar, contoh soal dan soal disampaikan dengan jelas, materi sudah pernah diajarkan sehingga cepat mudeng, mudah dipahami dan dihafalkan, media ini tidak rumit, dan menyenangkan.

\section{Pembahasan}

a. Pengembangan Media Pembelajaran Crossword Puzzle Accounting (CPA) berbasis Elektronik

1) Analysis

Produk yang sesuai untuk dikembangkan sebagai media pembelajaran dalam kompetensi dasar membuat jurnal penyesuaian akuntansi perusahaan dagang adalah dengan media pembelajaran berbasis elektronik khususnya komputer maupun laptop. Dalam hal ini materi pengajaran disusun secara sistematis dan dirancang dengan menggunakan bahasa pemrograman, perangkat lunak atau software animasi yaitu Macromedia Flash. Dengan adanya pembelajaran berbasis elektronik, siswa dapat lebih tertarik dan memahami materi jurnal penyesuaian akuntansi perusahaan dagang serta siswa dapat belajar dengan cara yang menyenangkan.

2) Design

Peneliti merancang konsep pengembangan media pembelajaran dengan menggunakan shapes pada Microsoft Word. Konsep pengembangan media pembelajaran berisi bagian-bagian apa saja yang akan ditampilkan di dalam media (storyboard).

Pada pengembangan media pembelajaran menyajikan materi, contoh soal, soal, dan evaluasi jurnal penyesuaian akuntansi perusahaan dagang. Konsep yang sudah matang dirancang di Microsoft Word untuk dijadikan acuan dalam pembuatan media pembelajaran berupa Crossword Puzzle Accounting (CPA) dengan menggunakan Macromedia Flash.

3) Development

Peneliti membuat media pembelajaran berupa berupa Crossword Puzzle Accounting (CPA) dengan menggunakan Macromedia Flash. Pengembangan media pembelajaran yang telah dibuat selanjutnya diuji kelayakannya oleh ahli materi, ahli media, dan praktisi pembelajaran akuntansi (guru). Ahli materi dan ahli media adalah dosen dari Jurusan Pendidikan Akuntansi dan Jurusan Akuntansi Fakultas Ekonomi Yogyakarta, sedangkan praktisi pembelajaran akuntansi adalah guru Akuntansi kelas $\mathrm{X}$ di SMK Negeri 1 Yogyakarta

4) Implementation

Siswa terlihat sangat antusias dan tertarik dalam pembelajaran menggunakan media pembelajaran Crossword Puzzle Accounting (CPA) berbasis elektronik ini. Selama pembelajaran menggunakan media ini, siswa tidak ada yang mengantuk dan mengobrol di luar materi pembelajaran. Siswa kelas X Ak 2 telah mendapatkan materi jurnal penyesuaian akuntansi perusahaan dagang sebelum peneliti melakukan penelitian. Pembelajaran dengan menggunakan media Crossword Puzzle Accounting (CPA) berbasis elektronik membawa suasana baru dalam mengajar dengan cara yang lebih menyenangkan.

b. Penilaian Media Pembelajaran Crossword Puzzle Accounting (CPA) berbasis Elektronik

1) Ahli Materi 
materi, $\begin{gathered}\text { Berdasarkan } \\ \text { media }\end{gathered}$ penilaian ahli Crossword Puzzle Accounting (CPA) berbasis elektronik memperoleh nilai rata-rata 4,36 yang berarti bahwa media pembelajaran tersebut "Sangat Layak" untuk diimplementasikan dalam pembelajaran ditinjau dari aspek relevansi materi, aspek pengorganisasian materi, aspek evaluasi/latihan soal, aspek bahasa, dan aspek efek bagi strategi pembelajaran.

Kelayakan materi ditinjau dari 26 butir pertanyaan yang terdiri dari 5 butir aspek relevansi materi, 7 butir aspek pengorganisasian materi, 7 butir aspek evaluasi/latihan soal, 2 butir aspek bahasa, dan 5 butir aspek efek bagi strategi pembelajaran. Hasil penilaian dari ahli materi 1 menunjukkan bahwa penilaian keseluruhan aspek memperoleh ratarata nilai 4,80 yang berarti "Sangat Layak", sedangkan penilaian dari ahli materi 2 menunjukkan bahwa penilaian keseluruhan aspek memperoleh rata-rata nilai 3,92 yang berarti "Layak".

2) Ahli Media

Berdasarkan penilaian ahli media, media pembelajaran Crossword Puzzle Accounting (CPA) berbasis elektronik memperoleh ratarata skor 4,26 yang berarti bahwa media pembelajaran tersebut "Sangat Layak" untuk diimplementasikan dalam pembelajaran ditinjau dari aspek bahasa, aspek rekayasa perangkat lunak, dan aspek tampilan visual.

Kelayakan media ditinjau dari 15 butir pertanyaan yang terdiri dari 3 butir aspek bahasa, 5 butir aspek rekayasa perangkat lunak, dan 7 butir aspek tampilan visual. Hasil penilaian dari ahli media menunjukkan bahwa penilaian keseluruhan aspek memperoleh rata-rata nilai 4,26 yang berarti "Sangat Layak".

3) Praktisi Pembelajaran Akuntansi (Guru Akuntansi)

Berdasarkan penilaian guru, media pembelajaran Crossword Puzzle Accounting (CPA) berbasis elektronik memperoleh nilai rata-rata 4,38 yang berarti bahwa media pembelajaran tersebut "Sangat Layak" untuk diimplementasikan dalam pembelajaran ditinjau dari aspek relevansi materi, aspek pengorganisasian materi, aspek evaluasi/latihan soal, aspek bahasa, aspek efek bagi strategi pembelajaran, aspek rekayasa perangkat lunak, dan aspek tampilan visual.

Kelayakan materi ditinjau dari 26 butir pertanyaan yang terdiri dari 5 butir aspek relevansi materi, 6 butir aspek pengorganisasian materi, 6 butir aspek evaluasi/latihan soal, 2 butir aspek bahasa, 4 butir aspek efek bagi strategi pembelajaran, 2 butir aspek rekayasa perangkat lunak, dan 1 butir aspek tampilan visual. Hasil penilaian dari guru 1 menunjukkan bahwa penilaian keseluruhan aspek memperoleh rata-rata nilai 4,46 yang berarti "Sangat Layak", sedangkan penilaian dari guru 2 menunjukkan bahwa penilaian keseluruhan aspek memperoleh rata-rata nilai 4,30 yang berarti "Sangat Layak".

\section{SIMPULAN DAN SARAN Simpulan}

Berdasarkan analisis data dan pembahasan di Bab IV, maka dapat disimpulkan bahwa:

a. Pengembangan media Crossword Puzzle Accounting (CPA) berbasis elektronik melalui empat tahap yaitu:

1) Analysis. Berdasarkan analisis produk yang sesuai untuk dikembangkan sebagai media pembelajaran dalam materi jurnal 
penyesuaian perusahaan dagang adalah Crossword Puzzle Accounting (CPA) berbasis elektronik.

2) Design. Pada tahap ini peneliti membuat desain media (storyboard); penyusunan materi, soal dan jawaban; pengumpulan dan pembuatan background, gambar, dan tombol; perangkat keras dan lunak yang dibutuhkan serta penyusunan instrumen penilaian media kemudian dilanjutkan pada tahap pengembangan media pembelajaran.

3) Development. Pada tahap ini dilakukan pembuatan media, validasi oleh ahli materi dan ahli media, revisi media, dan validasi oleh guru Akuntansi untuk dilakukan perbaikan/revisi produk untuk memperoleh produk akhir.

4) Implementation. Pada tahap ini media memperoleh presentase $\geq$ $65 \%$ dari siswa yang berarti media mendapat respon positif. Siswa berpendapat bahwa media dikemas dengan menarik, soal disampaikan dengan jelas, mendorong rasa ingin tahu, menambah pemahaman materi Akuntansi, dan menambah motivasi belajar Akuntansi.

b. Hasil penilaian media pembelajaran Crossword Puzzle Accounting (CPA) oleh ahli materi diperoleh rata-rata keseluruhan aspek yaitu 4,36 termasuk kategori "Sangat Layak"; ahli media diperoleh rata-rata 4,26 termasuk kategori "Sangat Layak"; dan praktisi pembelajaran Akuntansi diperoleh rata-rata 4,38 termasuk kategori "Sangat Layak".

c. Uji coba dilaksanakan di kelas $\mathrm{X}$ Akuntansi 2 SMK N 1 Yogyakarta. Hasil uji coba menunjukan "Respon Positif" karena semua indikator mendapatkan persentase $\geq 65 \%$. Dari data tersebut dapat disimpulkan bahwa menurut pendapat siswa media dikemas dengan menarik, contoh soal dan soal disampaikan dengan jelas, mendorong rasa ingin tahu untuk belajar Akuntansi, menambah pemahaman tentang Akuntansi, dan menambah motivasi dalam belajar Akuntansi.

\section{Saran}

Berdasarkan kualitas media, kelemahan dan keterbatasan penelitian yang telah dibahas sebelumnya, peneliti dapat memberikan beberapa saran pemanfaatan dan pengembangan media lebih lanjut sebagai berikut:

a. Sesuai dengan komentar dari ahli, media ini dapat dikembangkan pada materi lain yang lebih luas yaitu kompetensi dasar yang lain dengan waktu pengembangan yang lebih lama, sehingga cakupan materi akan lebih luas. Waktu penelitian yang lebih lama mendukung maksimalnya pembuatan desain serta revisi media yang dihasilkan menjadi lebih berkualitas.

b. Sesuai komentar dari praktisi pembelajaran Akuntansi, media Crossword Puzzle Accounting (CPA) akan lebih menarik jika bisa ditambahkan dengan materi dan soal yang berbeda.

c. Latihan soal perlu diperbanyak untuk menambah variasi soal pada media.

d. Media Crossword Puzzle Accounting (CPA) ini perlu dikembangkan lebih lanjut pada smartphone atau tablet android sehingga tidak hanya digunakan dalam laptop maupun komputer.

e. Untuk penelitian yang selanjutnya, sebaiknya uji coba media dilaksanakan lebih luas lagi sehingga menghasilkan suatu media pembelajaran yang baik dan dapat digunakan secara luas. 
f. Perlu adanya penelitian lebih lanjut untuk mengukur efektivitas penggunaan media misalnya dengan penelitian tindakan kelas.

\section{DAFTAR PUSTAKA}

Andi, Andreas. (2003). Menguasai Pembuatan Animasi dengan Macromedia Flash MX. PT Elex Media Komputindo: Jakarta.

Azhar Arsyad. (2011). Media Pembelajaran. Jakarta: Rajawali Pers.

Endang Mulyatiningsih. (2011). Metode Penelitian Terapan Bidang Pendidikan. Bandung: Alfabeta.

Hisyam. (2002). Strategi Pembelajaran Kooperatif. Jakarta: Rineka Cipta.

Madcoms. (2008). Adobe Flash CS3 Professional. Yogyakarta: Andi Offset.

Mel Silberman. (2009). Active Lerrning: 101 Metode Pembelajaran Aktif. Yogyakarta: Pustaka Insan Madani.

Romi Satria Wahono. (2006). Aspek dan Kriteria Penilaian Media Pebelajaran. Di akses melalui: http://romisatriawahono.net/2006/06/ 21/aspek-dan-kriteria-penilaianmedia-pembelajaran/.

Sugiyono. (2013). Metode penelitian pendidikan. Bandung: Alfabeta.

Sukardjo. (2012). Evaluasi Program Pembelajaran. Yogyakarta: Pps UNY. Tidak diterbitkan.

Sunoto. (2007). Analisis Data Statistik. Yogyakarta: Andi Publishing.

Tri Yuniyatul Khikmah. (2013). Pengembangan Media Pembelajaran Cd Interaktif Materi Struktur dan Fungsi Sel Dilengkapi Teka-Teki Silang Berbasis Flash. Disertasi, tidak dipublikasikan. Universitas Negeri Semarang.

Wina Sanjaya. (2012). Perencanaan dan Desain Sistem Pembelajaran. Jakarta: Kencana. 